\title{
Effects of Hydrolyzable Tannins on In Vitro Growth of Armillaria calvescens and A. gallica
}

Nicholas J. Brazee and Robert L. Wick, Department of Plant, Soil, and Insect Sciences, University of Massachusetts, 270 Stockbridge Rd., Fernald Hall, Amherst, MA 01003-9320; and Phillip M. Wargo, USDA Forest Service, Northern Research Station, 51 Mill Pond Rd., Hamden, CT 06514

\begin{abstract}
Brazee, N. J., Wick, R. L., and Wargo, P. M. 2011. Effects of hydrolyzable tannins on in vitro growth of Armillaria calvescens and A. gallica. Plant Dis. 95:1255-1262.

We hypothesized that Armillaria gallica, which is abundant in oakdominated forests, is more successful at oxidizing and metabolizing polyphenols than $A$. calvescens, which is mostly restricted to mapledominated forests. Isolates were challenged with up to seven concentrations of tannic acid (TA), gallic acid (GA), and black oak root bark extracts (RBE). Six concentrations of glucose and ethanol were also tested to determine the influence of available carbon on growth. Colony area and biomass values were analyzed using a GLM and Tukey's HSD test. When challenged with $0.12 \%$ concentrations of TA, GA, and RBE, A. gallica produced a significantly larger biomass in all

treatments and larger colony areas in four of the five treatments compared to control values. A. gallica also produced a significantly larger number of rhizomorphs than A. calvescens on RBE medium. In contrast, $A$. calvescens generated significantly larger biomass over control treatments only when RBE was added, and values were substantially less compared to A. gallica. Growth of both species was significantly greater when ethanol was added, especially on GA medium, while glucose had little effect. Results from this study suggest that $A$. gallica is better at oxidizing and metabolizing polyphenols than A. calvescens.
\end{abstract}

Armillaria calvescens Bérubé \& Dessureault and A. gallica Marxmüller \& Romagnesi are two very closely related species of Armillaria in North America. Both species create large, monopodial rhizomorph networks, primarily cause butt rot of hardwoods, produce nearly identical fruiting bodies, and have highly similar genetic profiles $(2,7,24)$. Surveys of Armillaria species distribution in northeastern North America have shown that A. calvescens occurs most frequently in maple-dominated forests, while A. gallica is more abundant in oak-dominated forests $(4,6,30,31)$. While $A$. gallica occurs in temperate forests throughout the Northern Hemisphere $(7,17,34)$, A. calvescens is restricted to northern hardwood/hemlock forests in eastern North America (2), with very few exceptions (26). In an attempt to better understand the differences between these two biological species, we assessed growth rates on polyphenol-amended media.

Plant polyphenols, the primary chemical defense of higher plants, are secondary metabolites that are known to inhibit the growth of parasitic fungi by restricting the production of cell-walldegrading enzymes, and also by disrupting and killing fungal cells through toxicity (15). Polyphenols are subdivided into two groups: one having a condensed flavonoid core (condensed tannins), and the other having a D-glucose core (hydrolyzable tannins) (19). Hydrolyzable tannins are the most abundant type in the leaves, bark, and wood of Quercus spp. and consist of various esters of gallic acid (GA) and ellagic acid (a dimer of gallic acid) $(20,27,35)$. Quercus species have been shown to produce polyphenols in the foliage and within the vascular cambium where these compounds are mobilized and stored within the heartwood, sapwood, and bark tissues for defense $(1,21,35,38)$. While variation

Corresponding author: N. J. Brazee, E-mail: nbrazee@ psis.umass.edu

* The $\boldsymbol{e}$-Xtra logo stands for "electronic extra" and indicates that Figure 1 appears in color in the online edition.

Accepted for publication 20 May 2011.

doi:10.1094/PDIS-02-11-0116

(C) 2011 The American Phytopathological Society occurs in the type and concentration of polyphenols in leaf tissue as the growing season progresses, the concentrations of bark polyphenols are stable (35).

Hydrolyzable tannins can be broken down into monomeric units by certain microorganisms, including Armillaria, which allows the glucose core to be metabolized as a food source $(3,39,44,45)$. When available carbon concentrations are low, polyphenols are effective at inhibiting the growth of Armillaria (12,14,39,43-45). Yet, if there are sufficient carbon and nitrogen sources for Armillaria, the fungus can overcome the inhibitory effects of polyphenols and oxidize and metabolize these compounds, thus stimulating growth $(14,39,45)$. In a study of polyphenol oxidation, Wargo (46) found that in white and black oak bark colonized by Armillaria, total polyphenols were reduced by 78 and 54\% compared to concentrations in uncolonized bark tissues, showing that Armillaria had successfully oxidized host polyphenols. The oxidized polyphenol levels in colonized bark were up to 3.5 times higher when compared to healthy, uncolonized bark. When Armillaria isolates were grown in extracts of white and black oak root bark, the addition of glucose and ethanol stimulated growth over carbon-unamended extracts (46). Yet, an increase in available carbon does not always correlate with enhanced degradation of polyphenolic compounds. Entry et al. (12) showed that while higher concentrations of simple sugars (glucose, fructose, and sucrose) increased in vitro growth of A. solidipes, the source and concentration of carbon had no effect on the degradation of catechol and para-hydroxybenzoic acid, two important plant defense compounds.

Along with reducing sugars, ethanol is present within the vascular cambium and xylem sap of trees, and increases considerably when trees are exposed to hypoxic or anoxic conditions (25). Root disease can also cause ethanol concentrations to increase in root phloem and sapwood. Kelsey and Joseph (23) found that Pseudotsuga menziesii infected with Leptographium wageneri had significantly elevated levels of ethanol in roots when compared to healthy trees. In vitro studies of Armillaria have proven that both rhizomorph and mycelium production are highly stimulated when ethanol is added to the growth medium $(50,51)$. When trees suffer defoliation from insects, root starch is converted back to reducing sugars for mobilization to the crown to refoliate (49). There is some evidence that increases of simple sugars in the cambial tissue 
can stimulate growth of Armillaria (49). However, it may be the increase of ethanol in conjunction with the increase in sugars that is stimulating the growth of Armillaria on host cambial tissues. Stress-induced increases of available carbon are believed to facilitate colonization of the cambium by Armillaria $(29,41,44,45)$.

Previous work on this subject was performed using various isolates of Armillaria mellea (sensu lato), since the complex of species that comprise the genus Armillaria in North America had not been fully elucidated $(10,43,45,46)$. Therefore, any variation encountered among A. mellea s.l. isolates could be potentially explained by differences among the species used. Shaw (39) found that growth rates on polyphenol media could not discriminate among six biological species of Armillaria from the Northern and Southern Hemisphere. But in contrast, Rishbeth (37) reported that growth rates on polyphenol media were useful for distinguishing four biological species from southern England.

The primary goals of this study were to: (i) determine whether there are significant differences in growth rates between $A$. gallica and $A$. calvescens on polyphenol media, and (ii) determine the effect that various glucose and ethanol amendments have on growth of each species on polyphenol media. We hypothesized that A. gallica will exhibit higher growth rates over A. calvescens within each polyphenol treatment, regardless of glucose and ethanol amendments. In addition, we hypothesized that growth of both species will be inhibited by increasing concentrations of purified polyphenols, but that root bark extracts will enhance growth. If our hypotheses are correct, this could help to explain why A. gallica is so abundant in mixed oak forests in northeastern North America, while A. calvescens is rarely found in this forest type.

\section{Materials and Methods}

Preparation of polyphenol media. Two commercially available hydrolyzable tannins were used: tannic acid (TA) (95\% pure, Acros Organics) and gallic acid (GA) (98\% pure, Acros Organics). In addition, black oak (Quercus velutina) root bark extracts (RBE) were used in this study. Root bark was collected just below the soil surface at the base of healthy trees by separating the bark from live sapwood using a chisel and hammer. The root bark was immediately placed on ice and returned to the laboratory within $1 \mathrm{~h}$ of harvest. It was then rinsed under tap water to remove soil, wrapped in cheesecloth, frozen at $-20^{\circ} \mathrm{C}$, and then freeze-dried in a lyophilizer for $72 \mathrm{~h}$. The outer suberized cork layer (phellem) was scraped off with a razor blade, and the remaining bark tissue (phloem) was ground to a fine powder in a Wiley mill using a 20-mesh screen.

The polyphenol medium was prepared as follows: a 5\% solution of each commercial polyphenol, TA or GA, was made by adding $40 \mathrm{~g}$ to $500 \mathrm{ml}$ of Weinhold's basal medium (BM) (50). The $\mathrm{pH}$ was then adjusted to 5.7 using $1 \mathrm{M} \mathrm{NaOH}$ and the volume increased to $800 \mathrm{ml}$ with $\mathrm{BM}$. The solution was then filter-sterilized under aseptic conditions. To create the RBE medium, a $1 \%$ solution of black oak root bark extracts was produced by mixing the ground root bark in warm BM at a concentration of $10 \%$ (wt/vol) for $15 \mathrm{~min}$. The mixture was then centrifuged for $15 \mathrm{~min}$ at 3,500 $\mathrm{rpm}$. The supernatant was removed and prefiltered through a $1-\mu \mathrm{m}$ filter, then filter-sterilized with a $0.45-\mu \mathrm{m}$ bottle-top filter under aseptic conditions. It was determined that approximately $10 \%$ of the RBE dissolves in solution, which was in agreement with previous work $(45,46)$. Each of the TA/GA/RBE treatments was made up of the proper volume of BM (adjusted to a $\mathrm{pH}$ of 5.7 with $1 \mathrm{M}$ $\mathrm{NaOH}$ ), with and without D-glucose when necessary. After the BM was autoclaved and cooled to $55^{\circ} \mathrm{C}, 95 \% \mathrm{EtOH}$ and the $5 \% \mathrm{TA} / \mathrm{GA}$ or $1 \%$ RBE solutions were added under aseptic conditions, as necessary, to produce the desired concentrations.

For the first phase of the study, seven concentrations of TA $(0$, $0.12,0.25,0.50,0.75,1.0$, and $2.0 \%)$ and GA $(0,0.12,0.25,0.38$, $0.50,1.0$, and $2.0 \%$ ) were tested. Four concentrations of RBE were used $(0,0.12,0.25$, and $0.50 \%)$. To assess the influence of simple carbon sources on polyphenol metabolism, six glucose and ethanol combinations were incorporated. These included: (i) control (BM only), (ii) glucose $=0.5 \%$, (iii) glucose $=1 \%$, (iv) ethanol $=0.1 \%$ $(\mathrm{vol} / \mathrm{vol}),(\mathrm{v})$ ethanol $=0.5 \%(\mathrm{vol} / \mathrm{vol})$, and $(\mathrm{vi})$ glucose $=0.5 \%+$ ethanol $=0.1 \%(\mathrm{vol} / \mathrm{vol})$. For the first phase of the study, three isolates of each species were used (six total) that had been collected previously from western Massachusetts (Table 1). After phase one was completed, we determined that more isolates per species were necessary and that the high polyphenol concentrations were not informative because they were very inhibitory to growth. For the second phase of this study, nine isolates of each species (18 total isolates, including the six isolates used in phase one) were used to test three GA/RBE concentrations $(0,0.12$, and $0.25 \%)$. All isolates of Armillaria used in this study were diploid. Because TA was not as informative at the lower concentrations $(0.12$ to $0.50 \%)$, and growth was poor at the higher concentrations ( 0.75 to $2 \%)$, its use was discontinued. Once again, six glucose and ethanol combinations were incorporated into each polyphenol treatment. In total, 548 cultures were produced in phase one, while 648 cultures were produced in phase two for a combined total of 1,296 cultures.

To ensure that growth on the solid polyphenol media was not influenced by any carryover of nutrients from the colonized plugs, all isolates were grown on water agar for approximately 3 weeks prior to transfer. Cultures older than 4 weeks were not used. A 5-mm plug was cut from the margins of each isolate colony for transfer to the polyphenol media. Within each $60 \times 15 \mathrm{~mm}$ petri dish, $12 \mathrm{ml}$ of medium was added to maintain consistency across treatments.

Table 1. Description of diploid Armillaria isolates tested on polyphenol media

\begin{tabular}{|c|c|c|c|c|c|}
\hline Species & No. & Isolate code & Host & Source tissue & Origin \\
\hline A. calvescens & $\begin{array}{l}1 \\
2 \\
3 \\
4 \\
5 \\
6 \\
7 \\
8 \\
9\end{array}$ & $\begin{array}{l}\text { M2-6y } \\
\text { G2- } 4^{y} \\
\text { P3-8 } \\
\text { G4-4z } \\
\text { TO2-12z } \\
\text { TO3-9z } \\
\text { Ac98 } \\
\text { Ac154 } \\
\text { ST17 (PR-3) }\end{array}$ & $\begin{array}{l}\text { Acer saccharum } \\
\text { Acer rubrum } \\
\text { Acer saccharum } \\
\text { Acer saccharum } \\
\text { Fagus grandifolia } \\
\text { Fraxinus americana } \\
\text { Acer saccharum } \\
\text { Acer saccharum } \\
\text { Acer saccharum }\end{array}$ & $\begin{array}{l}\text { Rhizomorphs } \\
\text { Rhizomorphs } \\
\text { Rhizomorphs } \\
\text { Rhizomorphs } \\
\text { Rhizomorphs } \\
\text { Rhizomorphs } \\
\text { Rhizomorphs } \\
\text { Rhizomorphs } \\
\text { Basidioma }\end{array}$ & $\begin{array}{l}\text { Massachusetts } \\
\text { Massachusetts } \\
\text { Massachusetts } \\
\text { Massachusetts } \\
\text { Massachusetts } \\
\text { Massachusetts } \\
\text { Ontario } \\
\text { Ontario } \\
\text { Michigan }\end{array}$ \\
\hline A. gallica & $\begin{array}{l}1 \\
2 \\
3 \\
4 \\
5 \\
6 \\
7 \\
8 \\
9\end{array}$ & $\begin{array}{l}\text { B2-6y } \\
\text { Q3-9y } \\
\text { H1-6y } \\
\text { W2-5z } \\
\text { S2-9z } \\
\text { D2-1 } \\
\text { MT5-1 } \\
\text { ST22 (EL-1) } \\
\text { ST23 (MA-1) }\end{array}$ & $\begin{array}{l}\text { Quercus velutina } \\
\text { Quercus velutina } \\
\text { Quercus velutina } \\
\text { Acer rubrum } \\
\text { Quercus velutina } \\
\text { Quercus alba } \\
\text { Pinus rigida } \\
\text { Betula papyrifera } \\
\text { Acer saccharum }\end{array}$ & $\begin{array}{l}\text { Rhizomorphs } \\
\text { Rhizomorphs } \\
\text { Rhizomorphs } \\
\text { Rhizomorphs } \\
\text { Rhizomorphs } \\
\text { Rhizomorphs } \\
\text { Rhizomorphs } \\
\text { Basidioma } \\
\text { Basidioma }\end{array}$ & $\begin{array}{l}\text { Massachusetts } \\
\text { Massachusetts } \\
\text { Massachusetts } \\
\text { Massachusetts } \\
\text { Massachusetts } \\
\text { Massachusetts } \\
\text { Massachusetts } \\
\text { Michigan } \\
\text { Wisconsin }\end{array}$ \\
\hline
\end{tabular}

${ }^{y}$ Indicates the isolates used in the first phase of the study (three isolates per species).

${ }^{\mathrm{z}}$ Indicates additional isolates used in the second phase of the study (nine isolates per species). Alternate isolate codes published previously listed in parentheses. 
Isolates in media were incubated in the dark at $25^{\circ} \mathrm{C}$ for 25 days, while in RBE medium, isolates were grown for only 18 days due to substantially faster growth.

Colony area $\left(\mathrm{mm}^{2}\right)$ was measured by capturing digital images in ImageJ (36). Petri dishes were scanned top-down alongside a metric ruler. Within ImageJ, a straight line was then drawn over a known length of the ruler (e.g., $50 \mathrm{~mm}$ ) to set the scale. A polygon was then manually constructed around the mycelial colony, and area was measured. This method is very accurate and well suited for a fungus like Armillaria which can produce diffuse, irregular colonies. The borders of each colony were set at the limits of thallus growth, while expanding rhizomorph networks were excluded from the total area. To determine dry biomass, solid cultures were removed from the plastic petri dishes and placed in open, glass petri dishes filled with water. The cultures were then placed in a steam autoclave for $1 \mathrm{~min}$ at operating temperature and pressure. Mycelial colonies were then removed from the dish with forceps, rinsed twice in water, and placed into preweighed 2-ml microcentrifuge tubes. The mycelium was then dried at $80^{\circ} \mathrm{C}$ for $48 \mathrm{~h}$ and immediately weighed after removal from the drying oven. Dry weights (in $\mathrm{mg}$ ) were obtained by subtracting the original tube weight. Despite establishing several treatments of Armillaria in polyphenol broth using vented-cap, $25 \mathrm{~cm}^{2}$ tissue culture flasks, and thick plugs that were elevated above the broth surface, several isolates simply did not grow, regardless of polyphenol concentration or glucose/ethanol amendments.

Identification of isolates used. Proper species identification was a critical component of this study. All isolates were initially identified using a polymerase chain reaction-restriction fragment length polymorphism (PCR-RFLP) protocol developed by McLaughlin and Hsiang (32) that targets variation in both the IGS1 and IGS-2 regions of the rDNA cluster (6). Confirmation of species identification was accomplished by analyzing partial sequences from the elongation factor 1-alpha (tefl) gene for 24 isolates (12 each) of A. calvescens and A. gallica, a set that includes all of the isolates used in this study. Partial tefl sequences were able to accurately distinguish all $A$. calvescens and A. gallica isolates that were previously identified using PCR-RFLP (5). Furthermore, tefl sequences have been shown to accurately distinguish closely related Armillaria species from both the Northern and Southern Hemisphere $(18,28)$.

Statistical analysis. A general linear model (GLM) was used for analysis of biomass and colony area data within SPSS 16.0 (SPSS Inc.). The univariate procedure was chosen, using both analysis of variance (ANOVA) and regression analysis to test a single dependent variable by multiple independent variables. The model was run with default settings; a full factorial model with type III sum of squares. Prior to running the GLM, the raw data were analyzed using residual plots and the Box-Cox procedure to determine if transformation was necessary (52). Based on these analyses, colony area and dry biomass were square root transformed. The GLM was used to determine if variation in colony area and biomass values could be explained by: (i) polyphenol (tannic acid, gallic acid, and root bark extracts) concentration; (ii) glucose/ethanol concentration (control, glucose $=0.5 \%$, glucose $=1.0 \%$, ethanol $=$ $0.1 \%$, ethanol $=0.5 \%$, and glucose $=0.5 \%+$ ethanol $=0.1 \%$ ) or presence of ethanol alone; and (iii) species (A. calvescens and $A$. gallica) or individual isolate. We also tested whether there were significant differences in rhizomorph development (presence or absence) between species for each polyphenol medium. In addition, isolates of $A$. calvescens were separated to test whether colony area and biomass were dependent upon their geographic origin. Specifically, A. calvescens isolates that originated from forests with significant components of red oak (Quercus rubra) and/or eastern hemlock (Tsuga canadensis) were tested against isolates that originated from northern hardwood forests without red oak or hemlock. Both red oak and hemlock are minor components of the northern hardwood forest type (13) and have higher concentrations and broader arrays of polyphenols present in their root bark (19). Forest composition data were used to determine origin criteria, and were collected previously with individual Armillaria isolates (6). Post-hoc analyses were done using the Tukey's honestly significant difference (HSD) test at $P=0.05$.

\section{Results}

Three isolates per species - Seven TA/GA concentrations and four RBE concentrations. Biomass. For TA, the highest level of variation was explained in the regression analysis using TA concentration, isolate, and ethanol (adjusted $r^{2}=0.84$ ). Based on ANOVA, significant differences in mean biomass between the two species by TA concentration were present only in the control treatment and at the highest (2\%) TA concentration (Table 2). A. calvescens produced significantly larger biomass values than A. gallica in the control treatment; yet overall values for $A$. calvescens were not significantly different across TA concentration, with the exception of the highest concentration (2\%) (Table 2). For A. gallica, the largest mean biomass occurred at the lowest concentration $(0.12 \%)$ and was more than double the control means (Table 2). Even with TA at $0.25 \%$, biomass was still significantly larger than the control treatment (Table 2). The addition of ethanol in the TA treatments didn't produce significant differences in biomass for A. gallica but did produce significantly larger biomass for A. calvescens $(P=$ 0.027) (data not shown). The presence of TA did not stimulate rhizomorph development over control treatments, and no significant differences in rhizomorph production occurred between species.

For GA, the regression analysis with the least amount of error (adjusted $r^{2}=0.93$ ) was achieved using GA concentration, isolate, and ethanol. Based on ANOVA, mean biomass values were significantly different between species only within the control treatment, where A. calvescens produced a mean biomass more than double that of A. gallica (Table 2). For A. calvescens, mean biomass values decreased as GA concentration increased, and while A. gallica produced its largest biomass levels at $0.12 \%$ GA (Table 2 ), values were not significantly different across all treatments. The addition of ethanol produced significantly larger biomass values for both $A$. calvescens and $A$. gallica within the GA treatment $(P=0.001$ and $P<0.001$, respectively), and in the highest concentrations $(0.38$ and $0.50 \%$ ) the presence of ethanol increased biomass more than 10-fold (data not shown, but results similar to the treatments using nine isolates per species were described in Table 3). Just as in the TA treatments, the addition of GA did not stimulate the production of rhizomorphs over control treatments and there were no differences in rhizomorph production between species.

For RBE, the least amount of variation was achieved with the regression analysis using RBE concentration, isolate, and ethanol (adjusted $r^{2}=0.92$ ). Results of the ANOVA showed that despite the strong effect of isolate, mean biomass values were significantly different between species within every treatment (Table 2). A. calvescens produced a significantly higher mean biomass compared to A. gallica within the control treatment, but A. gallica produced a significantly higher biomass in each of the RBE treatments (Table 2). Mean biomass values for $A$. calvescens were not significantly different across the four treatments $(P=0.055)$, while $A$. gallica produced a significantly larger biomass in each treatment $(P<0.001$; Table 2). Mean biomass produced by $A$. gallica at $0.5 \%$ RBE was over 10 times higher than that of the control treatment (Table 2).

Based on ANOVA, none of the glucose/ethanol treatments were significantly different between the two species (data not shown). Also, none of the isolates for either species produced rhizomorphs in the control treatment (BM only), but when RBE was added to the $\mathrm{BM}$, the presence of rhizomorphs was significantly higher for isolates of A. gallica compared to isolates of A. calvescens at concentrations of $0.12 \%(P<0.034), 0.25 \%(P<0.005)$, and $0.5 \%(P$ $<0.006$ ) (data not shown). Across all three RBE concentrations ( 0.12 to $0.5 \% ; n=108)$, A. gallica produced rhizomorphs in $27 / 54$ replicates $(50 \%)$, while $A$. calvescens produced rhizomorphs in $7 / 54$ replicates $(13 \%)(P<0.001)$.

Colony area. Results of the regression analyses for colony area were very similar to the biomass results, and only significant dif- 
ferences are listed here. For TA, the ANOVA showed that colony area was not significantly different within the control treatment, but A. gallica produced significantly larger colony areas than $A$. calvescens at the three highest TA concentrations $(0.75,1$, and $2 \%)$ (Table $2)$. At the highest TA concentration (2\%), A. gallica had a mean colony area more than 2.5 times that of A. calvescens (Table 2).

For GA, A. gallica produced significantly larger colony area values than A. calvescens at GA concentrations of $0.12 \%$ and $0.25 \%$ (Table 2). At GA concentration $0.25 \%$, A. gallica had a mean colony area almost twice that of $A$. calvescens (Table 2). For RBE, $A$. gallica produced significantly greater colony area values than $A$. calvescens at all three concentrations, $0.12,0.25$, and $0.50 \%$ (Table 2). At $0.50 \%$, A. gallica had a mean colony area more than twice that of $A$. calvescens (Table 2).

Nine isolates per species - Three GA/RBE concentrations. Biomass. For GA, the regression analysis using GA concentration, ethanol, and isolate once again yielded the lowest level of variation (adjusted $r^{2}=0.83$ ). Interestingly, when GA concentration is used alone, adjusted $r^{2}$ is extremely low (0.062), illustrating a major effect of individual isolate and ethanol on growth in GA medium. The effect of isolate in the model was again very strong for both $A$. calvescens and A. gallica $(P<0.001$ and $P<0.001$, respectively).
Across the three GA concentrations, pair-wise comparisons showed that $A$. calvescens biomass decreased significantly from the control to $0.25 \%$, while A. gallica biomass remained statistically unchanged from the control to $0.12 \%$, but then decreased significantly at $0.25 \%$ (Table 4 ).

When biomass values on GA medium are subdivided by the presence or absence of ethanol, the ANOVA showed that A. gallica biomass values were all statistically larger compared to the unamended treatments. Also, at the $0.25 \%$ GA treatment amended with ethanol, A. gallica biomass more than tripled compared to the unamended treatment (Table 3 ). The addition of ethanol was significant for $A$. calvescens biomass only at $0.25 \%$ GA (Table 3 ). Despite the positive ethanol effect, the only significant differences between species occurred in the control treatment (Table 3). However, from the control to $0.12 \% \mathrm{GA}$, A. calvescens biomass decreased with and without ethanol, while A. gallica biomass increased (Table 3). Again, the addition of GA to the medium did not stimulate production of rhizomorphs, as there were no significant differences in the number of replicates that produced rhizomorphs between species (data not shown).

For RBE biomass, the regression analysis using RBE concentration, isolate, and ethanol yielded an adjusted $r^{2}$ of 0.95 . Despite the

Table 2. Mean colony area (square millimeters) and mean biomass (milligrams) produced by Armillaria calvescens and A. gallica by concentration of tannic acid, gallic acid, and black oak root bark extracts in basal medium

\begin{tabular}{|c|c|c|c|c|c|c|}
\hline \multirow[b]{2}{*}{ \% Polyphenol } & \multicolumn{2}{|c|}{ Colony area } & \multirow[b]{2}{*}{$P$ value } & \multicolumn{2}{|c|}{ Biomass } & \multirow[b]{2}{*}{$P$ value } \\
\hline & A. calvescens $^{\mathrm{z}}$ & A. gallica & & A. calvescens & A. gallica & \\
\hline \multicolumn{7}{|l|}{ Tannic acid } \\
\hline 0 & $822(152) \mathrm{a}$ & $764(250) \mathrm{a}$ & 0.303 & 34.5 (19) a & 20.7 (13) ab & 0.014 \\
\hline 0.12 & $1,051(213) b$ & $1,074(103) b$ & 0.584 & $37.5(23) \mathrm{a}$ & $42.3(13) \mathrm{d}$ & 0.201 \\
\hline 0.25 & $886(135) \mathrm{a}$ & $810(133) \mathrm{a}$ & 0.089 & $28.3(17) \mathrm{a}$ & $30.4(9) \mathrm{c}$ & 0.309 \\
\hline 0.50 & $597(88) \mathrm{c}$ & $618(134) c$ & 0.648 & 26.7 (17) a & $22.8(5) b c$ & 0.790 \\
\hline 0.75 & $468(81) \mathrm{d}$ & $541(97) \mathrm{cd}$ & 0.021 & $26.7(12) \mathrm{a}$ & $22.4(5) b c$ & 0.318 \\
\hline 1.00 & $336(65) \mathrm{e}$ & $456(68) \mathrm{d}$ & $<0.001$ & $26.5(16) \mathrm{a}$ & $22.1(4) b c$ & 0.417 \\
\hline 2.00 & $98(27) \mathrm{f}$ & $251(41) \mathrm{e}$ & $<0.001$ & $11.0(6) b$ & $14.4(3) \mathrm{a}$ & 0.017 \\
\hline$P$ value & $<0.001$ & $<0.001$ & & 0.001 & $<0.001$ & \\
\hline \multicolumn{7}{|l|}{ Gallic acid } \\
\hline 0 & 788 (126) a & 689 (249) ab & 0.080 & $31.6(16) \mathrm{a}$ & $15.2(7) a b$ & $<0.001$ \\
\hline 0.12 & 733 (298) a & 998 (257) a & 0.005 & $21.2(14) \mathrm{ab}$ & $25.4(13) \mathrm{a}$ & 0.277 \\
\hline 0.25 & $350(247) \mathrm{b}$ & $660(356) b$ & 0.007 & $14.3(14) b c$ & $18.0(12) \mathrm{a}$ & 0.267 \\
\hline 0.38 & $127(132) \mathrm{c}$ & $242(219) \mathrm{c}$ & 0.114 & $8.8(11) \mathrm{c}$ & $9.3(9) \mathrm{bc}$ & 0.707 \\
\hline 0.50 & $82(66) \mathrm{c}$ & $118(125) \mathrm{c}$ & 0.378 & $6.4(7) \mathrm{c}$ & $8.1(10) \mathrm{c}$ & 0.708 \\
\hline 1.00 & No growth & No growth & -- & No growth & No growth & -- \\
\hline 2.00 & No growth & No growth & -- & No growth & No growth & -- \\
\hline$P$ value & $<0.001$ & $<0.001$ & & $<0.001$ & $<0.001$ & \\
\hline \multicolumn{7}{|c|}{ Root bark extracts } \\
\hline 0 & $432(103)$ & 458 (129) a & 0.569 & $17.7(10)$ & $10.6(7) \mathrm{a}$ & 0.012 \\
\hline 0.12 & $670(151)$ & 967 (207) b & $<0.001$ & $40.3(28)$ & $60.8(18) \mathrm{b}$ & 0.008 \\
\hline 0.25 & $580(301)$ & $1,098(324) b$ & $<0.001$ & $48.3(40)$ & $90.2(36) \mathrm{c}$ & 0.001 \\
\hline 0.50 & $519(461)$ & $1,163(452) b$ & $<0.001$ & $46.0(46)$ & $104.7(49) \mathrm{c}$ & $<0.001$ \\
\hline$P$ value & 0.044 & $<0.001$ & & 0.055 & $<0.001$ & \\
\hline
\end{tabular}

${ }^{\mathrm{z}}$ Total $n$ of 18 per polyphenol treatment (three isolates per species $\times$ six glucose/ethanol concentrations), with standard deviations in parentheses. Values are significantly different between species (row) and within species (column) at $P=0.05$. Values with different letters are significantly different within species at $P=0.05$ using the Tukey's HSD test.

Table 3. Colony area (square millimeters) and biomass (milligrams) produced by Armillaria calvescens and A. gallica on gallic acid medium by presence of ethanol (nine isolates per species)

\begin{tabular}{|c|c|c|c|c|c|c|c|}
\hline \multirow[b]{2}{*}{$\%$ Gallic acid } & \multirow[b]{2}{*}{ Ethanol } & \multicolumn{2}{|c|}{ Colony area } & \multirow[b]{2}{*}{$P$ value } & \multicolumn{2}{|c|}{ Biomass } & \multirow[b]{2}{*}{$P$ value } \\
\hline & & A. calvescens $^{\mathrm{z}}$ & A. gallica & & A. calvescens & A. gallica & \\
\hline 0 & No & 917 (419) a & 714 (134) ab & 0.024 & $22.0(25) \mathrm{ab}$ & $9.2(6) \mathrm{cd}$ & 0.009 \\
\hline 0 & Yes & 957 (379) a & $864(253)$ a & 0.320 & $33.4(23) \mathrm{a}$ & 20.7 (11) a & 0.017 \\
\hline 0.12 & No & $502(448) b$ & $638(185) b$ & 0.022 & $16.4(21) \mathrm{bc}$ & $13.1(8) b c$ & 0.968 \\
\hline 0.12 & Yes & 803 (446) a & $952(293)$ a & 0.084 & $28.6(23) a b$ & $24.9(11) \mathrm{a}$ & 0.800 \\
\hline 0.25 & No & $230(442) \mathrm{c}$ & $172(202) \mathrm{c}$ & 0.998 & $9.6(19) \mathrm{c}$ & $5.4(7) \mathrm{d}$ & 0.492 \\
\hline 0.25 & Yes & $466(419) \mathrm{b}$ & 575 (299) b & 0.118 & 20.4 (17) ab & $18.8(9) \mathrm{ab}$ & 0.774 \\
\hline$P$ value & & $<0.001$ & $<0.001$ & & $<0.001$ & $<0.001$ & \\
\hline
\end{tabular}

${ }^{\mathrm{z}}$ Total $n$ of 27 per polyphenol treatment (nine isolates per species $\times$ three ethanol concentrations), with standard deviations in parentheses. Values are significantly different between species (row) and within species (column) at $P=0.05$. Values with different letters are significantly different within species at $P=$ 0.05 using the Tukey's HSD test. 
strong isolate effect (Fig. 1), species was a significant predictor variable when used with RBE concentration alone in the regression model $(P=0.025)$. Results from the ANOVA showed that mean biomass was significantly different between species at the control and $0.25 \%$ RBE. A. calvescens produced a significantly higher mean biomass in the absence of RBE, while A. gallica produced significantly larger mean biomass at $0.25 \%$ RBE (Table 4). While the two species were not statistically different at $0.12 \%$ RBE, they were at $0.25 \%$, where the mean biomass produced by A. gallica was almost eight times higher than the control treatment $(P<$ $0.001)$ and almost two times higher than growth by A. calvescens $(P<0.001)$ (Table 4). A. calvescens biomass, meanwhile, only doubled from the control to $0.25 \%(P<0.001)$ (Table 4$)$.

None of the glucose/ethanol treatments were significantly different between the two species (data not shown). None of the isolates for either species produced rhizomorphs in the control treatment (BM only). However, when RBE was added to the BM, rhizomorph development occurred for both species but was significantly higher in isolates of A. gallica compared to A. calvescens. Specifically, in $0.12 \%$ RBE treatment, $A$. gallica produced rhizomorphs in $20 / 54(37 \%)$ replicates, compared to $2 / 54(4 \%)$ for A. calvescens $(P<0.001)$. In the $0.25 \%$ RBE treatments, $A$. gallica produced rhizomorphs in $39 / 54(72 \%)$ replicates, compared to $9 / 54$ for $A$. calvescens $(17 \%)(P<0.001)$.
Colony area. Once again, results for colony area were very similar to the biomass results; therefore, only significant trends that were not seen in the biomass are described. Based on the ANOVA of GA, A. gallica produced larger colony areas than A. calvescens only at $0.12 \%$ GA (Table 4$)$. While A. calvescens colony area decreased significantly and progressively from the control to 0.12 to $0.25 \% \mathrm{GA}$, A. gallica remained unchanged at $0.12 \% \mathrm{GA}$ and decreased significantly only after the increase from 0.12 to $0.25 \%$ GA (Table 4). For RBE, A. gallica once again produced significantly greater colony area values than $A$. calvescens at both RBE concentrations (Table 4). At $0.25 \%$, A. gallica had a mean colony area more than 1.5 times that of $A$. calvescens (Table 4).

Origin of A. calvescens isolates. Five of nine A. calvescens isolates originated from northern hardwood forests that had significant components of red oak and/or hemlock, whereas four came from pure northern hardwood stands. When ANOVA was used to test isolates by their origin, significant differences were apparent in both colony area and biomass (Table 5). On both GA and RBE media, mean biomass of isolates originating from forests with oak/hemlock was more than twice as large as the mean biomass of isolates from pure northern hardwoods (Table 5). One isolate of $A$. calvescens (Ac98), originating from a forest dominated by red oak, had large biomass values on GA medium that significantly skewed the overall mean of isolates originating from forests with

Table 4. Mean colony area (square millimeters) and biomass (milligrams) by gallic acid and root bark extract concentration by Armillaria species

\begin{tabular}{|c|c|c|c|c|c|c|}
\hline \multirow[b]{2}{*}{ \% Polyphenol } & \multicolumn{2}{|c|}{ Colony area } & \multirow[b]{2}{*}{$P$ value } & \multicolumn{2}{|c|}{ Biomass } & \multirow[b]{2}{*}{$P$ value } \\
\hline & A. calvescens ${ }^{\mathrm{z}}$ & A. gallica & & A. calvescens & A. gallica & \\
\hline \multicolumn{7}{|l|}{ Gallic acid } \\
\hline 0 & 937 (396) a & 789 (214) a & 0.023 & $27.7(25) \mathrm{a}$ & $15.0(11) \mathrm{ab}$ & 0.001 \\
\hline 0.12 & $653(468) b$ & 795 (290) a & 0.008 & $22.5(23) \mathrm{a}$ & $19.0(11) \mathrm{a}$ & 0.277 \\
\hline 0.25 & $348(438) \mathrm{c}$ & $374(324) b$ & 0.329 & $15.0(19) \mathrm{b}$ & $12.1(10) \mathrm{b}$ & 0.779 \\
\hline$P$ value & $<0.001$ & $<0.001$ & & 0.001 & 0.001 & \\
\hline \multicolumn{7}{|c|}{ Root bark extracts } \\
\hline 0 & 489 (227) a & 414 (147) a & 0.047 & $19.1(18) \mathrm{a}$ & $9.2(7) \mathrm{ab}$ & $<0.001$ \\
\hline 0.12 & $734(241) b$ & $973(326) \mathrm{b}$ & $<0.001$ & $35.6(21) \mathrm{b}$ & $42.8(23) \mathrm{b}$ & 0.113 \\
\hline 0.25 & $629(368)$ a & $1128(538) \mathrm{b}$ & $<0.001$ & $41.2(31) \mathrm{b}$ & $73.1(44) \mathrm{c}$ & $<0.001$ \\
\hline$P$ value & 0.170 & $<0.001$ & & $<0.001$ & $<0.001$ & \\
\hline
\end{tabular}

${ }^{\mathrm{z}}$ Total $n$ of 54 per polyphenol treatment (nine isolates per species $\times$ six glucose/ethanol concentrations), with standard deviations in parentheses. Values are significantly different between species (row) and within species (column) at $P=0.05$. Values with different letters are significantly different within species at $P=0.05$ using the Tukey's HSD test.
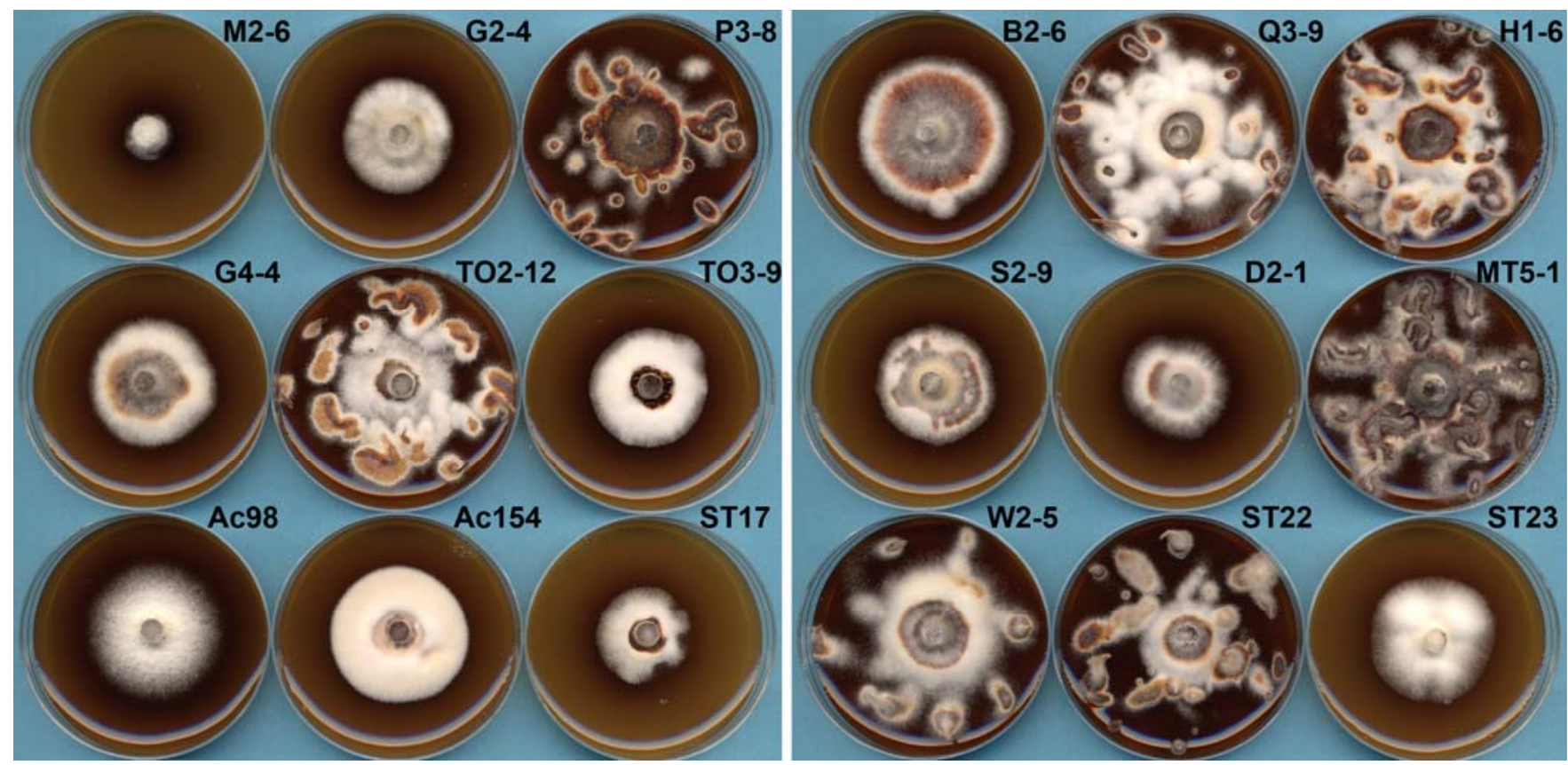

Fig. 1. Growth of nine Armillaria calvescens (left), and nine A. gallica isolates (right) after 18 days on black oak root bark extracts $(0.25 \%$ with $0.5 \%$ [vol/vol] $95 \%$ EtOH). Identification codes for each isolate appear in the upper right corner. 
oak/hemlock. When this isolate was removed from the analysis as an outlier, mean biomass decreased from 25.3 to $15.8 \mathrm{mg}$, but this mean was still significantly larger than the mean biomass of isolates originating from pure northern hardwoods (Table 5). Mean colony area of the isolates from the oak-dominated stands ranged from 1.5 to 3.5 times larger than the isolates from the pure northern hardwoods (Table 5).

Control versus $\mathbf{0 . 1 2 \%}$ treatments. The control treatment (no polyphenols added, six concentrations of glucose/ethanol) was carried out three times in the first phase of the study (three isolates per species, three polyphenol treatments) and twice in the second phase of the study (nine isolates per species, two polyphenol treatments). In each of these five control treatments, A. calvescens produced a significantly larger biomass than A. gallica (data not shown). In addition, within the two control treatments using nine isolates per species, A. calvescens produced significantly larger colony areas than A. gallica (data not shown). These results illustrate that $A$. calvescens exhibited higher growth rates in the absence of polyphenols.

When TA was added to the BM, A. gallica biomass values more than doubled from the control to $0.12 \% \mathrm{TA}$, while biomass values for $A$. calvescens were unchanged (Table 6). When GA was added to the BM (three isolates per species), A. gallica biomass again increased significantly from the control to $0.12 \% \mathrm{GA}$, while $A$. calvescens biomass decreased significantly from the control to $0.12 \%$ GA (Table 6). When GA was tested with nine isolates per species, the results were similar but with less significant $P$ values. The differences in growth on the black oak RBE were the most pronounced. When using nine isolates per species, A. calvescens biomass increased significantly from the control to $0.12 \% \mathrm{RBE}$, but growth for A. gallica was more substantial, producing a mean biomass over four times larger than the control (Table 6). Results using three per species were similar (Table 6).

\section{Discussion}

The primary goal of this study was to determine if differences in in vitro growth rates of $A$. calvescens and A. gallica occurred when the two species were challenged with varying concentrations of polyphenols. Despite the strong isolate effect and large standard deviations within treatments, the results of this study suggest that A. gallica is better at oxidizing and metabolizing polyphenols than A. calvescens across the gradient of concentrations tested. This was most apparent when comparing the results from the control and $0.12 \%$ polyphenol concentration, where $A$. calvescens produced a significantly larger colony area and biomass in the control treatments, and A. gallica produced a larger colony area and biomass when low levels of polyphenolic compounds were added to the medium. In addition, A. gallica replicates produced a significantly larger number of rhizomorphs on black oak RBE medium compared to A. calvescens. Therefore, it is possible that A. gallica is better able to oxidize and metabolize polyphenolic compounds present in the root bark of oaks in comparison to A. calvescens.
This could help explain the limited presence of A. calvescens in oak-dominated stands $(4,5)$.

The addition of available carbon to the polyphenol media showed that ethanol was the preferred carbon source over glucose. Glucose concentrations were doubled and tripled from the initial concentration $(0.5 \%)$ in the basal medium with little effect on growth. No significant differences in colony area and biomass were found between the control treatment and the two glucose treatments $(\mathrm{G}=0.5 \%$ and $\mathrm{G}=1.0 \%)$ across all three polyphenols tested in this study, regardless of the number of isolates per species. The addition of ethanol at 0.1 and $0.5 \%$ produced highly significant differences in both colony area and biomass, especially within the GA treatments. Wargo $(42,44)$ found root starch levels to be a good overall indicator of tree health, and that oaks with higher levels of root starch were more vigorous when faced with defoliation stress compared to oaks with lower levels of root starch. In contrast, elevated levels of ethanol indicate stress, as ethanol production in the stems of hardwoods increases dramatically when trees are exposed to hypoxic or anoxic conditions (25). Low oxygen conditions in roots, and subsequent ethanol production, can be induced in drier soils during seasonal wet periods especially when trees are defoliated, which leads to reduced water uptake and reduced transpira-

Table 6. Mean biomass (milligrams) by tannic acid (TA), gallic acid (GA), and root bark extracts (RBE) for control and $0.12 \%$ treatments by Armillaria species

\begin{tabular}{lccc}
\hline \% Polyphenol & A. calvescens & A. gallica & $P$ value \\
\hline TA $(3)^{\mathrm{z}}$ & & & \\
0 & $34.5(19)$ & $20.7(13)$ & 0.014 \\
0.12 & $37.5(23)$ & $42.3(13)$ & 0.201 \\
$P$ value & 0.965 & $<0.001$ & \\
GA $(3)$ & & & \\
0 & $31.6(16)$ & $15.2(7)$ & $<0.001$ \\
0.12 & $21.2(14)$ & $25.4(13)$ & 0.277 \\
$P$ value & 0.033 & 0.006 & \\
GA (9) & & & \\
0 & $27.7(25)$ & $15.0(11)$ & 0.001 \\
0.12 & $22.5(23)$ & $19.0(11)$ & 0.277 \\
$P$ value & 0.160 & 0.039 & \\
RBE (3) & & & \\
0 & $17.7(10)$ & $10.6(7)$ & 0.012 \\
0.12 & $40.3(28)$ & $60.8(18)$ & 0.008 \\
$P$ value & 0.010 & $<0.001$ & \\
RBE (9) & & & \\
0 & $19.1(18)$ & $9.2(7)$ & $<0.001$ \\
0.12 & $35.6(21)$ & $42.8(23)$ & 0.113 \\
$P$ value & $<0.001$ & $<0.001$ & \\
\hline
\end{tabular}

${ }^{\mathrm{z}}$ Treatments with three isolates per species had a total $n$ of 18 per polyphenol treatment (three isolates per species $\times$ six glucose/ethanol concentrations), while treatments with nine isolates per species had a total $n$ of 54 per polyphenol treatment (nine isolates per species $\times$ six glucose/ethanol concentrations), with standard deviations in parentheses.

Table 5. Colony area (square millimeters) and biomass (milligrams) of Armillaria calvescens isolates that originated from forests with and without significant components of oak and/or hemlock on gallic acid and root bark extracts media

\begin{tabular}{|c|c|c|c|c|c|c|c|}
\hline & \multicolumn{4}{|c|}{ Gallic acid } & \multicolumn{3}{|c|}{ Root bark extracts } \\
\hline & $0.12^{x}$ & 0.25 & 0.12 and 0.25 & 0.12 and $0.25^{y}$ & 0.12 & 0.25 & 0.12 and 0.25 \\
\hline \multicolumn{8}{|c|}{ Colony area } \\
\hline $\mathrm{P}-\mathrm{NH}^{\mathrm{z}}$ & 444 (316) & $146(176)$ & 295 (295) & 295 (295) & 577 (138) & 347 (184) & 462 (198) \\
\hline OH-NH & $820(507)$ & $510(514)$ & $500(476)$ & 459 (366) & 791 (206) & $828(352)$ & 857 (277) \\
\hline$P$ value & 0.001 & 0.001 & $<0.001$ & 0.009 & $<0.001$ & $<0.001$ & $<0.001$ \\
\hline \multicolumn{8}{|l|}{ Biomass } \\
\hline P-NH & $13.7(12)$ & $7.4(9)$ & $10.5(11)$ & $10.5(11)$ & $23.1(12)$ & $23.2(16)$ & $23.1(14)$ \\
\hline OH-NH & $29.4(27)$ & $21.1(22)$ & $25.3(25)$ & $15.8(17)$ & $47.1(22)$ & $59.3(35)$ & $50.7(27)$ \\
\hline$P$ value & 0.006 & 0.005 & $<0.001$ & 0.031 & $<0.001$ & $<0.001$ & $<0.001$ \\
\hline
\end{tabular}

${ }^{\mathrm{x}}$ Total $n$ of 54 per polyphenol treatment (nine isolates per species $\times$ six glucose/ethanol concentrations), with standard deviations in parentheses.

${ }^{\mathrm{y}}$ Excluding Ac98 from analysis as an outlier.

${ }^{\mathrm{z}}(\mathrm{P}-\mathrm{NH})$ isolates that originated from pure northern hardwood forests (beech-birch-maple) and (OH-NH) isolates that originated from northern hardwood forests with red oak and/or hemlock. 
tion $(9,40)$. Therefore, Armillaria may have evolved to respond to increases in ethanol because of the correlation with elevated stress levels, which was clearly shown with wood-boring insects and oak (33). In comparison, elevated levels of simple sugars may not always stimulate growth of Armillaria as effectively because high starch levels have been shown to correspond with greater tree vigor against attack from insects and pathogens (11).

In contrast to other published reports of Armillaria growth on TA- and GA-added media $(8,37,39)$, neither of these compounds stimulated rhizomorph development in this study over control treatments, and growth at $0.5 \% \mathrm{GA}$ was poor. Yet overall, the data are conflicting, as Rishbeth (37) also reported that rhizomorph production and mycelial growth were restricted on gallic acid medium compared to TA medium. In addition, Davidson et al. (10) reported none to trace growth for 12 isolates of A. mellea s.l. on $0.5 \%$ GA medium and minimal growth (colony diameter $<25 \mathrm{~mm}$ ) on $0.5 \%$ TA medium. Media preparation across all of these studies, including this one, was fairly consistent, and these conflicting data could be an isolate effect. In this study, growth at $0.5 \%$ GA was poor, and growth was completely inhibited at concentrations of $1 \%$ GA. The previous studies listed above used TA and GA at a $0.5 \%$ concentration exclusively, with Shaw (39) using the same basal medium used in this study, while Rishbeth (37) and Davidson et al. (10) used $1.5 \%$ MEA as basal medium. The only major difference was in isolate preparation, as Shaw (39) and Rishbeth (37) grew their isolates on $3 \%$ MEA, while our isolates were grown on water agar (Davidson et al. did not describe isolate preparation). The carryover of nutrients or the initiation of polyphenol oxidase production on MEA could have allowed Armillaria to oxidize TA and GA with greater success than seen in this study. The black oak root bark extracts were highly stimulatory to rhizomorph development (Fig. 1), which is consistent with field observations of A. gallica in mixed oak forests $(41,48)$. Overall, this medium appeared to produce the most quantifiable variation in growth among isolates within and between species.

Our findings suggest that certain A. calvescens isolates are effective at oxidizing and metabolizing polyphenols, but it stills remains unclear why A. calvescens is not present in mixed oak forests, as maple, birch, and beech are present in mixed oak forests in southern New England (13). While our focus has been on the polyphenols present in the host tissue, it should not be overlooked that host polyphenols ultimately become incorporated into the soil as trees die and decay. Despite the high similarity to A. gallica, A. calvescens appears to exhibit reduced plasticity in regards to the range of sites it can occupy. Soil temperature and moisture could play a role in restricting $A$. calvescens to cooler, wetter forest types like northern hardwoods (4). Likewise, A. gallica may grow best in warmer, drier soil types and is consequently restricted from occupying northern hardwood forests above certain latitudes or elevations. Elevation has proven to have a significant role in the distribution of Armillaria species across a range of forest types $(22,47)$. While $A$. gallica is widely distributed throughout temperate regions in the northern hemisphere (16), A. calvescens only occurs in the Upper Midwest and Appalachian Mountains in eastern North America (7). This study sheds some light on why A. calvescens does not occur in mixed oak forests, but there are still several questions that remain unanswered, such as why A. gallica is not as abundant in maple-dominated forests as A. calvescens, and what site factors are influencing the distribution of these two species.

\section{Acknowledgments}

This material is based on work supported by the National Institute of Food and Agriculture, U.S. Department of Agriculture, the Massachusetts Agricultural Experiment Station, and the Department of Plant, Soil, and Insect Sciences under Project No. MAS00099.

\section{Literature Cited}

1. Bates-Smith, E. C., and Metcalfe, C. R. 1957. Leuco-anthocyanins: The nature and systematic distribution of tannins in dicotyledenous plants. Bot. J. Linnean Soc. 55(362):669-705.

2. Bérubé, J. A., and Dessureault, M. 1989. Morphological characterization of the Armillaria mellea complex: Two new species A. gemina and A. calvescens. Mycologia 81:216-225.

3. Bhat, T. K., Singh, B., and Sharma, O. P. 1998. Microbial degradation of tannins - A current perspective. Biodegradation 9:343-357.

4. Blodgett, J. T., and Worrall, J. J. 1992. Distributions and hosts of Armillaria species in New York. Plant Dis. 76:166-170.

5. Brazee, N. J. 2011. Armillaria in Massachusetts Forests: Ecology, Species Distribution, and Population Structure, with an Emphasis on Mixed Oak Forests. University of Massachusetts, Amherst.

6. Brazee, N. J., and Wick, R. L. 2009. Armillaria species distribution from symptomatic hosts in northern hardwood and mixed oak forests in western Massachusetts. For. Ecol. Manage. 258:1605-1612.

7. Burdsall, H. H., and Volk, T. J. 1993. The state of taxonomy of the genus Armillaria. McIlvania 11:4-12.

8. Cheo, P. C. 1982. Effects of tannic acid on rhizomorph production by $A r$ millaria mellea. Phytopathology 72:676-679.

9. Crawford, R. M. M., and Baines, M. A. 1977. Tolerance of anoxia and the metabolism of ethanol in tree roots. New Phytol. 79:519-526.

10. Davidson, R. W., Campbell, W. A., and Blaisdell, D. J. 1938. Differentiation of wood-decaying fungi by their reactions on gallic or tannic acid medium. J. Agric. Res. 57:683-695.

11. Dunn, J. P., Kimmerer, T. W., and Potter, D. A. 1987. Winter starch reserves of white oak as a predictor of attack by the twolined chestnut borer, Agrilus bilineatus (Weber) (Coleoptera : Buprestidae). Oecologia 74:352-355.

12. Entry, J. A., Donnelly, P. K., and Cromack, K. J. 1992. The influence of carbon nutrition on Armillaria ostoyae growth and phenolic degradation. Eur. J. For. Pathol. 22:149-156.

13. Eyre, F. H. 1980. Forest Cover Types of the United States and Canada. Society of American Foresters, Washington, D.C.

14. Garraway, M. O., Huttermann, A., and Wargo, P. M. 1991. Ontogeny and physiology. Pages 21-47 in: Armillaria Root Disease. U.S. Dep. Agric. Agric. Handb. No. 691.

15. Goldstein, J. L., and Swain, T. 1965. The inhibition of enzymes by tannins Phytochemistry 4:185-192.

16. Guillaumin, J. J., Anderson, J. B., and Korhonen, K. 1991. Life cycle, infertility, and biological species. Pages 10-20 in: Armillaria Root Disease. U.S. Dep. Agric. Agric. Handb. No. 691.

17. Guillaumin, J. J., Mohammed, C., Anselmi, N., Courtecuisse, R., Gregory, S. C., Holdenrieder, O., Intini, M., Lung, B., Marxmuller, H., Morrison, D., Rishbeth, J., Termorshuizen, A. J., Tirro, A., and Vandam, B. 1993. Geographical distribution and ecology of the Armillaria species in Western Europe. Eur. J. For. Pathol. 23:321-341.

18. Hasegawa, E., Ota, Y., Hattori, T., and Kikuchi, T. 2010. Sequence-based identification of Japanese Armillaria species using the elongation factor-1 alpha gene. Mycologia 102:898-910.

19. Haslam, E. 1998. Practical Polyphenolics: From Structure to Molecular Recognition and Physiological Action. Cambridge University Press, Cambridge, UK.

20. Haslam, E., and Scalbert, A. 1987. Chemical defence and polyphenols of Quercus robur. Phytochemistry 26:3191-3195.

21. Hathaway, D. 1959. Experiments on the origins of oak-bark tannin. Biochem. J. 71:533-537.

22. Keča, N., Karadžić, D., and Woodward, S. 2009. Ecology of Armillaria species in managed forests and plantations in Serbia. For. Pathol. 39:217231.

23. Kelsey, R. G., and Joseph, G. 1998. Ethanol in Douglas-fir with black-stain root disease (Leptographium wageneri). Can. J. For. Res. 28:1207-1212.

24. Kim, M.-S., Klopfenstein, N. B., Hanna, J. W., and McDonald, G. I. 2006 Characterization of North American Armillaria species: Genetic relationships determined by ribosomal DNA sequences and AFLP markers. For. Pathol. 36:145-164.

25. MacDonald, R., and Kimmerer, T. 1991. Ethanol in the stems of trees Physiol. Planatar. 82:582-588.

26. Mallett, K. I. 1990. Host range and geographic distribution of Armillaria root rot pathogens in the Canadian prairie provinces. Can. J. For. Res. 20:1859-1863.

27. Mämmelä, P., Savolainen, H., Lindroos, L., Kangas, J., and Vartiainen, T. 2000. Analysis of oak tannins by liquid chromatography-electrospray ionisation mass spectrometry. J. Chromatog. 891:75-83.

28. Maphosa, L., Wingfield, B. D., Coetzee, M. P. A., Mwenje, E., and Wingfield, M. J. 2006. Phylogenetic relationships among Armillaria species inferred from partial elongation factor 1-alpha DNA sequence data. Australas. Plant Pathol. 35:513-520.

29. Marçais, B., and Breda, N. 2006. Role of an opportunistic pathogen in the decline of stressed oak trees. J. Ecol. 94:1214-1223.

30. Marçais, B., and Wargo, P. M. 2000. Impact of liming on the abundance and vigor of Armillaria rhizomorphs in Allegheny hardwoods stands. Can. J. For. Res. 30:1847-1857.

31. McLaughlin, J. A. 2001. Distribution, hosts, and site relationships of Armillaria spp. in central and southern Ontario. Can. J. For. Res. 31:1481-1490.

32. McLaughlin, J. A., and Hsiang, T. 2010. Identification protocol for six Armillaria species from northeastern North America. Can. J. For. Res 40:536-548.

33. Montgomery, M. E., and Wargo, P. M. 1983. Ethanol and other host-derived 
volatiles as attractants to beetles that bore into hardwoods. J. Chem. Ecol. 9:181-190.

34. Ota, Y., Matsushita, N., Nagasawa, E., Terashita, T., Fukuda, K., and Suzuki, K. 1998. Biological species of Armillaria in Japan. Plant Dis. 82:537-543.

35. Parker, J. 1977. Phenolics in black oak bark and leaves. J. Chem. Ecol. 3:489-496.

36. Rasband, W. S. 1997-2010. ImageJ. US National Institutes of Health, Bethesda, MD.

37. Rishbeth, J. 1986. Some characteristics of English Armillaria species in culture. Trans. Br. Mycol. Soc. 86:213-218.

38. Seikel, M. K., Hostettler, F. D., and Niemann, G. J. 1971. Phenolics of Ouercus rubra wood. Phytochemistry 10:2249-2251.

39. Shaw, C. G., III 1985. In vitro responses of different Armillaria taxa to gallic acid, tannic acid, and ethanol. Plant Pathol. 34:594-602.

40. Stephens, G. R., Turner, N. C., and Deroo, H. C. 1972. Some effects of defoliation by gypsy moth (Porthetria dispar L.) and elm spanworm (Ennomos subsignarius Hbn.) on water balance and growth of deciduous forest trees. For. Sci. 18:326-330.

41. Twery, M. J., Mason, G. N., Wargo, P. M., and Gottschalk, K. W. 1990. Abundance and distribution of rhizomorphs of Armillaria spp. in defoliated mixed oak stands in western Maryland. Can. J. For. Res. 20:674-678.

42. Wargo, P. M. 1975. Estimating starch content in roots of deciduous trees - a visual technique. U.S. Dep. Agric. For. Serv. RP-NE-313.

43. Wargo, P. M. 1980. Interaction of ethanol, glucose, phenolics and isolate of Armillaria mellea. Phytopathology 70:470.
44. Wargo, P. M. 1981. Measuring response of trees to defoliation stress. Pages 225-267 in: The gypsy moth: Research toward integrated pest management. C. C. Doane and K. A. McManus, eds. U.S. Dep. Agric. For. Serv. Tech Bull. 1584.

45. Wargo, P. M. 1983. The interaction of Armillaria mellea with phenolic compounds in the bark of roots of black oak. Phytopathology 73:838.

46. Wargo, P. M. 1984. Changes in phenols affected by Armillaria mellea in bark tissue of roots of oak, Quercus spp. Pages 198-206 in: Proc. 6th Int. Conf. Root Butt Rots For. Trees. International Union of Forestry Research Organizations (IURFO). G. A. Kile, ed. Melbourne, Australia.

47. Wargo, P. M., Carey, A. C., Geballe, G. T., and Smith, W. H. 1987. Occurrence of rhizomorphs of Armillaria in soils from declining red spruce stands in three forest types. Plant Dis. 71:163-167.

48. Wargo, P. M., and Montgomery, M. E. 1983. Colonization by Armillaria mellea and Agrilus bilineatus of oaks injected with ethanol. For. Sci. 29:848-857.

49. Wargo, P. M., Parker, J., and Houston, D. R. 1972. Starch content in roots of defoliated sugar maple. For. Sci. 18:203-204.

50. Weinhold, A. R. 1963. Rhizomorph production by Armillaria mellea induced by ethanol and related compounds. Science 142:1065-1066.

51. Weinhold, A. R., and Garraway, M. O. 1966. Nitrogen and carbon/nutrition of Armillaria mellea in relation to growth promoting effects of ethanol Phytopathology 56:108-112.

52. Zar, J. H. 2007. Biostatisical Analysis: 5th ed. Prentice Hall, Upper Saddle River, NJ. 